\title{
Reactions of Soybean Cultivars to Phytophthora megasperma var. sojae Isolated from Shizuoka
}

\author{
Takahito Suzui* \\ 鈴井孝仁*：静岡県から分離された Phytophthora megasperma \\ var. sojae に対するダイズ品種の反応
}

Key Words : Phytophthora megasperma var. sojae, cultivars reaction.

Phytophthora root rot of soybean (Glycine max (L.) Merr.), caused by Phytophthora megasperma var. sojae, was first reported by Suhovecky et al. ${ }^{1)}$ in Ohio in 1955. In Japan, Tsuchiya $e t a l .{ }^{2}$ reported the occurrence of Phytophthora root and stem rot in Hokkaido in 1978. The disease was also recognized in Shizuoka Prefecture during 1978 and 1979, particularly on drained paddy fields and upland fields. This report deals with the reaction of different soybean cultivars to 3 isolates of $P$. megasperma var. sojae from Shizuoka.

Soybean cultivars affected in field by the root and stem rot were Enrei, Tozan 112, Nakahata, Hamamatsu-Zairai and Fujimusume. Phytophthora sp. was successfully isolated from diseased tissues when PDA or BNPRA + HMI supplemented PDA media ${ }^{3)}$ were used. Morphological features of sporangia, oogonia, antheridia and oospores, and cardinal temperatures of isolate N5 (IFO 31015) from cv. Enrei, isolate G 3 (IFO 31014) from Nakahata and isolate $\mathrm{H} 12$ (IFO 31016) from Hamamatsu-Zairai, were identical with those of $P$. megasperma var. sojae described by Hildebrand ${ }^{4}$.

Inoculation of soybean and other leguminous plants was made by the hypocotyl method $^{5)}$. Alfalfa (Medicago sativa L. subsp. sativa) was inoculated by either hypocotyl or soil drench methods ${ }^{6}$. Soybean $\mathrm{cv}$. Tamanishiki was killed by inoculation with Phytophthora isolate N5, G3 and H12. No symptoms, however, appeared on alfalfa cv. Moapa, kidney bean (Phaseolus vulgaris), broad bean (Vicia faba), pea (Pisum sativum), cowpea (Vigna sinensis) and peanut (Arachis hypogaea) when these were inoculated with either one of three isolates. On the basis of the above results, the fungus was identified as Phytophthora megasperma var. sojae Hildebrand 1959. Kuan and Erwin ${ }^{7)}$ proposed that $P$. megasperma can be subdivided into two speciales, P. megasperma f. sp. medicaginis for the isolates that attack alfalfa and $P$. megasperma f. sp. glycinea for the isolates that attack soybean. Accordingly the isolates N5, G 3 and H 12 were considered to belong to the $P$. megasperma f. sp. glycinea, since the isolates attacked only soybean.

* Shizuoka Agricultural Experiment Station, Toyoda-cho, Shizuoka 438, Japan 静岡県農業試験場 1) Suhovecky, A. J. and Schmitthenner, A. F. (1955). Ohio Farm Home Res. 40: 85-86. 2) Tsuchiya, S., Kodama, F., Akai, J. and Muramatsu, Y. (1978). Ann. Phytopath. Soc. Japan 44: 351. 3) Masago, H., Yoshikawa, M., Fukada, M. and Nakanishi, N. (1977). Phytopathology 67:425-428. 4) Hildebrand, A. A. (1959). Can. J. Bot. 37: 927-957. 5) Laviolett, F. A. and Athow, K. L. (1971). Phytopathology 61: 439-440. 6) Erwin, D. C. (1966). Ibid. 56:653-657. 7) Kuan, T-L. and Erwin, D. C. (1980). Ibid. 70: 333-338. 
In an attempt to identify the races for the isolates, inoculation test to different soybean cultivars was carried out by the hypocotyl method ${ }^{5)}$ keeping inoculated plants in phytotron for 6 days at the temperatures of 25 and $21 \mathrm{C}$ during the day and night time respectively. After inoculation wilting and dying of the plants were observed. The soybean cultivars used for inoculation were the United States differential cultivars (Harosoy, Sanga, Harosoy 63, Mack, Altona, PI 103091, PI 171442, Tracy) and Japanese cultivars (Tamanishiki, Enrei, Fukuyutaka, Tozan 112, Tozan 113, Hogyoku, Akiyoshi, Fujimusume, Akisengoku, Hamamatsu-Zairai). The test was repeated 4 times.

The isolate G 3 attacked all of the 10 Japanese cultivars used, whereas isolate N 5 and $\mathrm{H} 12$ killed the 7 Japanese cultivars but not Fukuyutaka, Tozan 112 and Tozan 113 (Table 1). The three isolates killed all of the U.S. differential cultivars (Table 2). These results may indicate the existence of physiological races of $P$. megasperma var. sojae in Japan as reported by Kodama et al. ${ }^{8)}$ Keeling ${ }^{9)}$ added 4 new physiological races of $P$. megasperma f. sp. glycinea and have been identified 20 races. However, the isolates in Shizuoka were different from them of $P$. megasperma f. sp. glycinea. Also the results obtained differed from those reported by Komada et al ${ }^{8}$ ) in Hokkaido and by Sato et al. ${ }^{10)}$ in Yamagata. Three isolates from Shizuoka are probably new races. Recently, Tsuchiya et al. ${ }^{11\rangle}$ reported that $P$. megasperma var. sojae collected from Hokkaido and Yamagata could be divided into 9 groups from the pathogenicity test using Japanese soybean cultivars. It is suggested that investigations on the physiological races of $P$. megasperma var. sojae require the use of a larger number of isolates collected over wide areas and numerous Japanese soybean cultivars for the establishment

Table 1. Pathogenicity of Phytophthora megasperma var. sojae isolates N5, G 3 and H12 from soybean in Shizuoka to Japanese soybean cultivars

\begin{tabular}{lccc}
\hline \multirow{2}{*}{$\begin{array}{c}\text { Japanese soybean } \\
\text { cultivars }\end{array}$} & \multicolumn{3}{c}{ Wilt of plants } \\
\cline { 2 - 4 } & $\begin{array}{c}\text { Isolate } \\
\text { N5 }\end{array}$ & G3 & H12 \\
\hline Tamanishiki & + & + & + \\
Enrei & + & + & + \\
Fukuyutaka & - & + & - \\
Tozan 112 & - & + & - \\
Tozan 113 & - & + & - \\
Hogyoku & + & + & + \\
Akiyoshi & + & + & + \\
Fujimusume & + & + & + \\
Akisengoku & + & + & + \\
Hamamatsu-Zairai & + & + & + \\
\hline
\end{tabular}

a) +: wilt, - : healthy
Table 2. Pathogenicity of Phytophthora megasperma var. sojae isolates N5, G 3 and H12 from soybean in Shizuoka to the United States differential soyben cultivars

\begin{tabular}{lccc}
\hline \hline \multirow{2}{*}{$\begin{array}{c}\text { U. S. } \\
\text { soybean } \\
\text { differential } \\
\text { cultivars }\end{array}$} & $\begin{array}{c}\text { Wsolate } \\
\text { N5 }\end{array}$ & G3 & H12 \\
\cline { 2 - 4 } Harosoy & + & + & + \\
Sanga & + & + & + \\
Harosoy 63 & + & + & + \\
Mack & + & + & + \\
Altona & + & + & + \\
PI 103091 & + & + & + \\
PI 171442 & + & + & + \\
Tracy & + & + & + \\
\hline
\end{tabular}

a) + : wilt

8) Kodama, F. and Tsuchiya, S. (1979). Ann. Phytopath. Soc. Japan 45: 529. 9) Keeling, B. L. (1982). Plant Dis. 66: 334-335. 10) Sato, T., Kobayashi, N. and Komada, H. (1981). Ann. Rept. Plant Prot. North Japan 32: 115-116. 11) Tsuchiya, S., Tanaka, F. and Kodama, F. (1982). Ann. Phytopath. Soc. Japan 48: 348. 
of races in Japan.

The author wishes to thank Dr. E. E. Hartwig, Delta Branch Experiment Station, Stoneville, Mississippi, Dr. R. L. Bernard, U. S. Regional Soybean Laboratory, Seed Stock Laboratory, Institute of National Agriculture Sciences, Japan, Dr. K. Hashimoto, Tohoku National Agriculture Experiment Station, Messrs. K. Kitazawa and N. Matsumoto, Hokkaido National Agriculture Experiment Station, for the collection of seeds.

(Received March 18, 1982) 